\title{
Hospitalization costs associated with diarrhea among children during the period of rotavirus circulation in the Northwest region of Argentina
}

\author{
Norberto D. Giglio, M.D., ${ }^{a}$ Martín Caruso, M.D., ${ }^{b}$ Vanesa E. Castellano, M.D., ${ }^{a}$ \\ Liliana Choque, B.S., ${ }^{b}$ Silvia Sandoval, B.S., ${ }^{b}$ Paula Micone, M.D. ${ }^{c}$ \\ and Ángela Gentile, M.D. ${ }^{a}$
}

\begin{abstract}
Objective. To assess direct medical costs, outof-pocket expenses, and indirect costs in cases of hospitalizations for acute diarrhea among children $<5$ years of age at Hospital de Niños "Héctor Quintana" in the province of Jujuy during the period of rotavirus circulation in the Northwest region of Argentina.

Methods. Cross-sectional study on diseaserelated costs. All children $<5$ years of age, hospitalized with the diagnosis of acute diarrhea and dehydration during the period of rotavirus circulation between May $1^{\text {st }}$ and October $31^{\text {st }}$ of 2013, were included. The assessment of direct medical costs was done by reviewing medical records whereas out-of-pocket expenses and indirect costs were determined using a survey. For the $95 \%$ confidence interval of the average cost per patient, a probabilistic bootstrapping analysis of 10000 simulations by resampling was done.

Results. One hundred and five patients were enrolled. Their average age was 18 months (standard deviation: 12); 62 (59\%) were boys. The average direct medical cost, out-of-pocket expense, and lost income per case was ARS3413.6 (2856.35-3970.93) (USD 577.59), ARS 134.92 (85.95-213.57) (USD 22.82), and ARS 301 (223.28380.02) (USD 50.93), respectively. The total cost per hospitalization event was ARS3849.52 (32984402.25) (USD 651.35).

Conclusions. The total cost per hospitalization event was within what is expected for Latin America. Costs are broken down into direct medical costs (significant share), compared to out-of-pocket expenses $(3.5 \%)$ and indirect costs $(7.8 \%)$.

Key words: Childhood diarrhea, rotavirus, health expenditure, personal finance.
\end{abstract}

http: / / dx.doi.org/10.5546/ aap.2017.eng.527

Norberto D. Giglio, M.D.: norbergiglio@gmail. com

\section{Funding:}

This study was funded by an unrestricted grant awarded by Merck Sharp \& Dohme Corp. Argentina.

Conflict of interest:

See page $x x x$.

Received: 11-29-2016

Accepted: 4-24-2017

\section{INTRODUCTION}

Rotavirus infection affects mainly children younger than 5 years and caused approximately 528000 deaths per year before the vaccine was introduced. It has been estimated that, following vaccine introduction, mortality has reduced to a half. ${ }^{1}$

More than $90 \%$ of deaths occur in developing countries. In Argentina, between 1100000 and 1250000 cases of acute diarrhea are reported each year, and $45-50 \%$ occur in children younger than 5 years. The highest rate of rotavirus-associated diarrhea is in the Northwest region of Argentina (NOA), with $41.6 \%$ of positive results out of all samples analyzed in the 2009-2011 period. ${ }^{2,3}$

Jujuy, a province on the border with Bolivia, is among the regions of Argentina with the largest indigenous population or descendants of indigenous peoples belonging to nine different ethnic groups. Part of this population lives in rural areas in the mountains, away from the capital city. Also, $53 \%$ of the population living in Jujuy has some kind of health coverage whereas $15 \%$ has unmet basic needs. ${ }^{4-6}$

Certain characteristics such as health care patterns, difficulties to provide a close follow-up in outpatient offices, and caregivers' level of education and beliefs lead to assuming that in the province of Jujuy there may be specific utilization and cost patterns.

The objective of this study was to assess direct medical costs, out-ofpocket expenses, and indirect costs in cases of hospitalizations for acute diarrhea in children $<5$ years of age 
at Hospital de Niños "Héctor Quintana" in the province of Jujuy during the period of rotavirus circulation in the NOA.

\section{MATERIAL AND METHODS}

This was a cross-sectional study conducted during the rotavirus circulation period among children younger than 5 years who attended the Hospital de Niños "Héctor Quintana", in the capital city of Jujuy. This is a tertiary care (level III) referral hospital for the entire province with approximately 170000 visits and 5500 discharges each year.

The rotavirus circulation period was estimated to be between May $1^{\text {st }}$ and October $31^{\text {st }}$ of 2013, based on the prevalence of viral circulation in the previous years. ${ }^{3}$

All patients who met the definition of acute diarrhea ${ }^{7}$ and who also required hospitalization for oral rehydration therapy (plan B) or intravenous rehydration therapy $(\text { plan } C)^{8}$ were included in the study. Patients whose parents refused to participate in the study were excluded.

Once the informed consent was signed, direct medical costs were assessed by reviewing medical records. All resources associated with each day of hospitalization, diagnostic tests, and medications were included.

Out-of-pocket expenses and indirect costs were obtained based on a structured survey administered to parents or caregivers based on the World Health Organization's Guidelines for estimating the economic burden of diarrheal disease, with focus on assessing the costs of rotavirus diarrhea. ${ }^{9}$ The survey was translated into Spanish, cross-culturally adapted, and pilottested (see Annex 1).

Transportation, private office consultation visits, medication, and other expenses incurred by parents or caregivers were included. Any lost income related to absenteeism from work was considered an indirect cost.

Nurses trained on cost assessment collected data from medical records and administered the survey to parents or caregivers.

Unit costs were described in Argentine pesos based on health care service rates corresponding to the second semester of 2013. The exchange rate was USD 1= ARS 5.91 based on the average price recorded for that semester. Unit costs were provided by the hospital's Department of Administration.

The mean and standard deviation (SD) for quantitative outcome measures were estimated using the Epi Info software, version $6.0 ;^{10}$ confidence intervals (CIs) of ratios or percentages were calculated with OpenEpi 2.2.1. ${ }^{11}$ To estimate the $95 \%$ CI of the average cost per patient, a probabilistic bootstrapping analysis of 10000 simulations by resampling was done. ${ }^{12}$

The protocol was approved by the Provincial Committee of Bioethics of the General Division of Health Research of the province of Jujuy.

\section{RESULTS}

During the study period, 105 patients were hospitalized for acute diarrhea; of these, 93 received an initial diagnosis of diarrhea in the Emergency Department, and 12 were diagnosed with diarrhea-associated dehydration. Most patients were from urban populations $(90.4 \%)$. All parents and caregivers accepted to participate in the study.

The average age of patients was 18 months old (SD: 12); 62 (59.04\%) were boys, and $41(39.4 \%)$ of cases had a history of prior infections, mostly pneumonia, followed by urinary tract infection and a history of anemia and bronchial hyperresponsiveness.

Out of all hospitalized patients, 77 (73.3\%) had made a previous visit to the hospital's Emergency Department and their stay lasted 2.57 hours (SD: 3.05), and 44 (41.9\%) had visited the outpatient offices, with a stay that lasted 1.37 hours (SD: 1.54); 16 patients had visited both the Emergency Department and the outpatient offices.

Once hospitalized, patients' hydration status was assessed and $19(18.1 \%), 83(79.5 \%)$, and $3(2.86 \%)$ had mild, moderate, and severe dehydration, respectively. None of the hospitalized patients required admission to the intensive care unit and nor died as a result of the cause of hospitalization. Table 1 describes resource utilization and unit costs at the hospital.

Out of all patients, $41(39.05 \%)$ received antipyretics; $27(25.71 \%)$, antacids; $6(5.71 \%)$, antiemetics; and $30(28.57 \%)$, antibiotics. The total medication cost was ARS 235.18 (USD 39.79) per patient. Table 2 describes the average direct medical costs of the studied sample.

In relation to out-of-pocket expenses, 58 patients indicated that they had paid for private office consultation visits, medications, and diagnostic methods for an average expense of ARS 146.94, CI: 87.45-206.43 (USD 24.86, CI: 14.97-34.92), and the average expense per hospitalization event was ARS 81.16, CI: 48.3-114 (USD 13.73, CI: 8.17-19.28) for all cases. 
Families of the 105 hospitalized patients spent an average of 1 hour to get to the hospital $(57.5 \mathrm{~h}$, SD: 53). In terms of means of transportation, $74(70.48 \%)$ families used the bus; $27(25.71 \%)$, took a cab or a private taxi; $3(2.86 \%)$ arrived by ambulance; and 1, by foot. To get to the hospital, families made an average of $2.47+1.54$ trips prior to hospitalization and $3.19+3.6$ trips while the child was hospitalized. The total average cost per trip prior to and during hospitalization was ARS 53.74, CI: 37.69-99.57 (USD 9.09, CI: 6.3716.84) per patient. Based on these findings, it was possible to estimate an average out-of-pocket expense per hospitalization event of ARS 134.92, CI: 85.99-213.57 (USD 22.82, CI: 14.54-36.13).

In relation to indirect costs, among all surveyed participants, 104 parents referred an average lost income of ARS 301, CI: 223.28-380.02 (USD 50.93, CI: 37.78-64.3) per hospitalization event. Of these families, $56(53.33 \%)$ reported that they had a stable job or worked in a store.

Based on these findings, the cost per event per hospitalized child was estimated at ARS 3849.52, CI: 3298-4402.25 (USD 651.35, CI: 558.03-744.88).

\section{DISCUSSION}

Consistent with what has been described in the epidemiology of this disease, our results show that diarrhea episodes during the rotavirus circulation period mostly affect children younger than 2 years, and a correlation was observed between the protocol-defined period and rotavirus circulation in the study year. ${ }^{2}$

Medical costs for a patient hospitalized for diarrhea were estimated at ARS 3849.52 (USD 651.35). Although it is very difficult to compare costs among different countries, our results are similar to those described by other authors. Takemoto et al. ${ }^{13}$ stated that, for a total of 21 studies conducted in Latin America, the cost per hospitalized patient ranged from USD 95.65 to USD 1002.10, with a mean of USD 400.58.

In relation to cost breakdown structure, most publications describe that direct medical costs account for most costs compared to out-ofpocket expenses and indirect costs. In our study, productivity losses and out-of-pocket expenses accounted for $3.5 \%$ and $7.8 \%$, respectively, of the total cost per hospitalization event. In the United

TABLE 1. Resource utilization and unit costs $(N=105)$

\begin{tabular}{|c|c|c|c|}
\hline & No. of subjects & $\begin{array}{l}\text { Average units used } \\
\text { and SD }\end{array}$ & Unit cost in ARS \\
\hline Visit to the hospital office & $44(41.9 \%)$ & 1 & 55 \\
\hline Visit to the Emergency Department & $77(73 \%)$ & 1 & 54 \\
\hline Hospital day & $105(100 \%)$ & $4.26+3.96$ & 637 \\
\hline Parasitology (stools) & $12(11.43 \%)$ & 1 & 22.5 \\
\hline Leukocytes (stools) & $89(84.76 \%)$ & $1.01+0.10$ & 22.5 \\
\hline Stool culture & $54(51.43 \%)$ & $1.05+0.23$ & 60 \\
\hline Electrolytes & $67(63.8 \%)$ & $1.4+1.03$ & 26.25 \\
\hline Blood glucose & $57(54.29 \%)$ & $1.26+0.74$ & 11.25 \\
\hline Urea & $65(61.9 \%)$ & $1.2+0.66$ & 11.25 \\
\hline Creatinine & $41(39.05 \%)$ & $1.14+0.42$ & 15 \\
\hline Blood count & $88(83.81 \%)$ & $1.14+0.57$ & 22.5 \\
\hline Blood culture & $8(7.6 \%)$ & $1.37+0.91$ & 56.75 \\
\hline X-ray & $32(30.4 \%)$ & $1.78+1.75$ & 50 \\
\hline Fecal virus (ELISA) & $34(32.38 \%)$ & 1 & 100 \\
\hline ORS* & $69(65.7 \%)$ & $2.21+1.57$ & 33.5 \\
\hline Intravenous rehydration vials & $102(97.14 \%)$ & $5.1+2.96$ & 33.5 \\
\hline
\end{tabular}

*ORS: oral rehydration solution; SD: standard deviation; ELISA: enzyme-linked immunosorbent assay.

TABLE 2. Direct medical costs $(N=105)$

\begin{tabular}{ll}
\hline Average cost of a visit to the Emergency Department & AR\$ 39.6 (USD 6.7) \\
Average cost of a visit to a hospital office & AR\$ 23.04 (USD 3.89) \\
Total average cost associated with hospital length of stay & AR\$ 2713.6 (IC 2238.46-3188.73) (USD 459.15, IC 378.75-539.54) \\
Total average cost of diagnostic tests and treatment & AR\$ 637.39 (IC 557.98-716.8) (USD 107.84, IC 94.41-121.15) \\
Medical cost per hospitalization event & AR\$ 3413.6 (IC 2856.35-3970.93) (USD 577.59, IC 483.3-671.9) \\
\hline
\end{tabular}


States, the cost per hospitalization event for gastroenteritis was estimated at USD 4780, where out-of-pocket expenses accounted for $1.2 \%$ and indirect costs, 5\%. ${ }^{14}$ In Kenya, the direct medical costs of hospitalized patients were estimated to be between USD 173 and USD 231; productivity losses, at USD $10(4 \%)$; and transportation expenses, at USD $20(8 \%) .{ }^{15}$ The predominance of medical costs over out-of-pocket expenses and productivity losses in association with hospitalization for diarrhea was also described by Rheingans et al. ${ }^{16}$ in 2007; the same distribution pattern is observed in Argentina, Brazil, Chile, Dominican Republic, Honduras, Mexico, Panama, and Venezuela.

Unlike what has been described before, the study conducted in Taiwan among patients hospitalized for rotavirus gastroenteritis showed that the cost per event was USD 874, direct medical costs accounted for USD $382(43.7 \%)$, out-of-pocket expenses, USD $294(33.63 \%)$, and indirect costs, USD $185(22.67 \%){ }^{17}$

The economic conditions of each country may account for cost proportions described here. In Argentina, the rate of unemployment and the cost of public transportation services explain the differences observed between direct medical costs, out-of-pocket expenses, and indirect costs associated with productivity losses.

In the province of Jujuy, the estimated rate of employment was $37 \%^{18}$ and together with the low cost of public transportation, which is subsidized by the government, ${ }^{19}$ result in the families of hospitalized patients $(70.48 \%)$ incurring in low costs.

Considering that the minimum salary for the fourth quarter of 2014 was ARS 4716 (USD 535.90), ${ }^{20}$ a hospitalization for gastroenteritis has an impact on family income and may reduce it by up to $9.2 \%$. The same scenario has been described in Argentina by Gentile et al. ${ }^{21}$ regarding costs associated with hospitalization for Bordetella pertussis, where out-of-pocket expenses and productivity losses accounted for $4 \%$ of the total event costs; this meant an $8 \%$ reduction in the average salary for each family of hospitalized patients.

Our study has some limitations because it was conducted in only one hospital and most patients came from urban areas, and this may result in a bias of provincial or rural area representativity. The costs quantified in this study were related to hospitalizations for diarrhea during the rotavirus circulation period but it was not confirmed whether these infections were actually associated with rotavirus; this may result in a bias regarding the implications of costs associated with this disease.

Finally, considering that the population of children younger than 5 years in Jujuy is 60753 inhabitants, ${ }^{22}$ with an annual hospitalization rate of diarrhea patients prior to vaccine introduction of 9000 per 100000 children, ${ }^{23,24}$ it is expected that there would be 5468 hospitalizations for acute diarrhea, $41 \%$ of which would be caused by rotavirus. ${ }^{3}$ From the perspective of society, the annual cost related to acute diarrhea would be USD 3561 582, of which USD 1460248 would correspond to rotavirus diarrheas.

Acute diarrhea is one of the main causes of avoidable morbidity and mortality caused by dehydration among children younger than 5 years in developing countries. Rotavirus diarrhea prevention via immunization together with oral rehydration therapy and timely access to health care services constitute a fundamental strategy to prevent hospitalizations and deaths.

Argentina introduced the rotavirus vaccine in 2015 in a schedule of 2 doses at 2 and 4 months old. Based on effectiveness and efficacy data developed in the region, a major reduction in the burden of disease and diarrhea-associated costs are expected in the next years.

\section{CONCLUSION}

Our findings show that the total cost per hospitalization event is within what is expected for Latin America. Costs are broken down into direct medical costs (significant share), compared to out-of-pocket expenses $(3.5 \%)$ and indirect costs $(7.8 \%)$.

\section{Conflict of interest}

None of the authors is related to Merck Sharp \& Dohme Corp. Argentina in this study and have not charged a fee.

Angela Gentile, M.D., and Norberto Giglio, M.D., have received occasional fees for consulting services provided to this company that were unrelated to the contents of this study.

\section{REFERENCES}

1. Tate JE, Burton AH, Boschi-Pinto C, et al. Global, Regional, and National Estimates of Rotavirus Mortality in Children $<5$ years of age, 200-2013. Clin Infect Dis 2016;62 Suppl 2: S96-105.

2. Sistema Nacional de Vigilancia de la Salud. Años 20052013. Ministerio de Salud de la Nación. Datos extraídos de los lineamientos técnicos. Fundamentos de la 
introducción de la vacuna contra rotavirus al Calendario Nacional 2015. [Accessed on: April 26 $6^{\text {th }}$, 2017]. Available at: http: / / www.msal.gob.ar/images/stories / bes / graficos / 0000000586cnt-2014-12_lineamientos-rotavirus. pdf.

3. Degiuseppe J I, Giovacchini C, Stupka JA, et al. Vigilancia epidemiológica de rotavirus en la Argentina: 2009-2011. Arch Argent Pediatr 2013;111(2):148-54.

4. García Moritán M, Cruz MB. Comunidades originarias y grupos étnicos de la provincia de Jujuy. Poblac Soc 2012; 19(2):155-73.

5. Argentina. Instituto Nacional de Estadísticas y Censos. Población Originaria. In: Censo nacional de población, hogares y viviendas 2010: Censo del Bicentenario: resultados definitivos. Serie Bn.o2. Buenos Aires: INDEC, 2012: 275-91. [Accessed on: April 25 ${ }^{\text {th }}$, 2017]. Available at: http:/ / www. estadistica.sanluis.gov.ar/estadisticaWeb/Contenido/ Pagina148/File/LIBRO/censo2010_tomo1.pdf.

6. Argentina. Instituto Nacional de Estadísticas y Censos. Necesidades Insatisfechas. In: Censo nacionaldepoblación, hogares y viviendas 2010: Censo del Bicentenario: resultados definitivos.Serie B n.o 2. Buenos Aires: INDEC, 2012:309-20. [Accessed on: April 25 ${ }^{\text {th }}$, 2017]. Available at: http:/ / www. estadistica.sanluis.gov.ar/estadisticaWeb/Contenido/ Pagina148/File/LIBRO/censo2010_tomo1.pdf.

7. Organización Panamericana de la Salud. Conceptos esenciales relativos a la diarrea. Definición de la diarrea. In: Tratamiento de la diarrea:Manual Clínico para los Servicios de Salud. Washington, D.C.: OPS, 2008:3. [Accessed on: April 25 ${ }^{\text {th }}$, 2017]. Available at: http:/ / apps.who.int/iris / bitstream/10665/166083/1/9789275329276.pdf.

8. Organización Panamericana de la Salud. Tratamiento de la diarrea aguda (sin sangre) Plan B: tratamiento de rehidratación oral para niños con algún grado de deshidratación. Plan C: tratamiento de los pacientes con deshidratación grave. In: Tratamiento de la diarrea: Manual Clínico para los Servicios de Salud. Washington, D.C.: OPS,2008:15-21. [Accessed on: April $\left.25^{\text {th }}, 2017\right]$. Available at: http://apps.who.int/iris/ bitstream/10665/166083/1/9789275329276.pdf.

9. World Health Organization. Guidelines for estimating the economic burden of diarrhoeal disease, with focus on assessing the costs of rotavirus diarrhoea. Geneva: WHO,2002. [Accessed on: April 25 ${ }^{\text {th }}$, 2017]. Available at: http: / / apps.who.int/iris / bitstream / 10665 / 69137 / 1 / WHO_IVB_05.10.pdf.

10. CDC. EpiInfoTMversion 6. [Accessed on: April 25 ${ }^{\text {th }}$, 2017]. Available at: https://wwwn.cdc.gov/epiinfo/html/ei6_ downloads.htm.

11. Dean AG, Sullivan KM, Soe MM. OpenEpi: Open Source Epidemiologic Statistics for Public Health, Versión. www. OpenEpi.com, updated on 2013/04/06, accessed on 2016/08/19.
12. Gray A, Clarke P, Wolstenholme J, Wordsworth Applied Methods of Cost-effectiveness Analysis in Health Care. Oxford University Press 2011. ISBN 978-0-19-922728-0.

13. Takemoto ML, Bahia L, Toscano CM, et al. Systematic review of studies on rotavirus disease cost-of-illness and productivity loss in Latin America and the Caribbean. Vaccine 2013;31(Suppl 3):C45-57.

14. Widdowson MA, Meltzer MI, Zhang X, et al. Costeffectiveness and potential impact of rotavirus vaccination in the United States. Pediatrics 2007;119(4):684-97.

15. Osano BO, Wang'ombe JK, Kamenwa RW, et al. Cost analysis of care for children admitted to Kenyatta national hospital with rotavirus gastroenteritis. Vaccine 2011; 29(23):4019-24

16. Rheingans RD, Constenla D, Antil L, et al. Economic and health burden of rotavirus gastroenteritis for the 2003 birth cohort in eight Latin American and Caribbean countries. Rev Panam Salud Publica 2007;21(4):192-204.

17. Chen KT, Fan SF, Tang RB, et al. Hospital-based study of the economic burden associated with rotavirus diarrhea in Taiwan. Vaccine 2007;25(21):4266-72.

18. Jujuy. Dirección Provincial de Estadísticas y Censos. Tasa deEmpleo 2009-2015. Secretaría General de la Gobernación. [Accessed on: January 2016]. Available at: http://www. dipec.jujuy.gov.ar/is_trabajoeingresos.html.

19. Argentina. Ministerio de Transporte. [Accessed on: April $27^{\text {th }}$,2017]. Available at: https:// servicios.transporte.gob. ar/compensaciones/.

20. Argentina. Ministerio de Trabajo, Empleo y Seguridad Social. Ingresos, salarios y distribución. Boletín de Estadísticas laborales. [Accessed on: April $5^{\text {th }}$, 2017]. Available at: http: / / trabajo.gob.ar/left/estadisticas/bel/index.asp.

21 Gentile A, Salgueiro A L, García Bournissen F, et al. Costos de la enfermedad por Bordetellapertussis en hospitales terciarios de la Argentina. Arch Argent Pediatr 2013;111(4):295-302.

22. Dirección General de Epidemiologia. Perfil de salud de la provincia de Jujuy. Una introducción sobre la situación general. Jujuy: Ministerio de Salud,2013. [Accessed on: April $27^{\text {th }}$, 2017]. Available at: http:/ / www.msaludjujuy. gov.ar:8081/panel/bol/2013/Perfil_de_salud_de_la_ provincia_de_Jujuy_2013.pdf.

23. Dirección General de Epidemiologia. Boletín Quincenal de Diarreas Agudas de la Provincia de Jujuy. Jujuy: Ministerio de Salud, 2014;24 (SE 48). [Accessed on: April 27 th, 2017]. Available at: http://www.msaludjujuy.gov.ar:8081/ panel/bol/2014/Boletin_Diarrea_SE_482014.pdf.

24. Organización Panamericana de la Salud. Vigilancia epidemiológica de diarreas causadas por rotavirus: guía práctica. Washington, DC:OPS, 2007. [Accessedon: April $\left.25^{\text {th }}, 2017\right]$. Available at: http:/ / cidbimena.desastres.hn/ filemgmt/ files/guiapractica_rotavirus.pdf. 


\section{ANNEX}

QUESTIONNAIRE ABOUT OUT-OF-POCKET EXPENSES AND INDIRECT COSTS

1. Record number:

2. Facility name:

3. Facility code:

4. Type of facility where you sought care prior to hospitalization:

Tertiary care hospital

$$
\text { Public Trade union health insurance Private }
$$

\section{General hospital}

Health care center

\section{Patient information}

- ID number:

- Medical record number:

- Date of birth:

- Sex: -Male -Female

- Informed consent date:

- Origin: -Urban -Rural -Unknown

- Relationship between the patient and the caregiver:

- Mother

- Father

- Sister

- Brother

- Grandfather

- Grandmother

- Friend

- Other family member

6. How long did it take you to get to the hospital from your home?:

Minutes Hours Unknown

7. What kind of transportation do you use to get here? (in case of multiple means of transportation, please tick only the means of transportation that is used for the longest distance):

- Car (your own or from a family member)

- Bus

- Train

- Bicycle

- Motorbike

- Cab or private taxi

- By foot

- Boat

- Ambulance

- Other 
8. If you pay for transportation to come to the hospital, please specify how much you pay every time you come here (write 0 if no payment is made):

9. How many trips did you and your child make prior to hospitalization?:

10. How many times did you make the same trip since your child was hospitalized until discharge?:

11. If you paid for transportation to make these visits, please specify how much you paid in total (write 0 if no payment was made):

12. Before visiting this facility, how much did you spend in medication, diagnostic tests, and consultation visits?:

13. Have you lost working days (income) for coming to the hospital?: -Yes -No

14. If you weren't here today, what would you be doing?:

- Nothing

- Housework

- Looking after my children

- Working (specify):

- Other (specify):

- Don't know

15. How much income have you and other family members lost as a result of coming to the hospital with your child since hospitalization until discharge?

16. How many people share your household?

- Adults: $\quad-18-28$ years old: $-29-38$ years old: $-39-48$ years old: $\quad-49$ years or older:

- Children: $\quad-0-5$ years old: $\quad-6-10$ years old: $-11-17$ years old:

Survey completed by:

Identity document:

Date: 